\title{
VARIATION CHARACTERISTICS, INFLUENCING FACTORS AND HYDROLOGICAL CONDITIONS OF THE REVERSE FLOW FROM MEKONG RIVER TO TONLE SAP LAKE
}

\author{
LI, C. W. - You, Z. Q. - LI, A. Q. - XU, Z. M. - YAO, W. - HuANG, L. Y. \\ Changjiang Institute of Survey, Planning, Design and Research, Wuhan 430010, China \\ *Corresponding author: Li Changwen \\ e-mail: lichangwen@cjwsjy.com.cn \\ (Received 21 $1^{\text {st }}$ May 2019; accepted $2^{\text {nd }}$ Sep 2019)
}

\begin{abstract}
In order to understand the interactive mechanism between Mekong River and Tonle Sap Lake, long-series hydrological statistics were studied to analyze the variation characteristics, influencing factors and hydrological conditions of the reverse flow from Mekong River to Tonle Sap Lake. It was found that the reversal in the flood season lasts 122 days, with the flow volume reaching 37.7 billion $\mathrm{m}^{3}$ and flood peak flow reaching $8402 \mathrm{~m}^{3} / \mathrm{s}$ on average. The reversal reaches the maximum in August, accounting for $43 \%$ of the total yearly volume and $17.7 \%$ of the flow in Mekong River. Main factors influencing reversal flow include the difference in the runoff and water level between Mekong River and Tonle Sap Lake, and the water level of Tonle Sap River. The hydrological conditions presupposed that the reversal flow is linearly correlated to the product of water-level of Tonle Sap River to the power of 1.36 multiplied by that water-level difference to the power of 0.46. The result is expected to provide a scientific basis for the management of Mekong Delta and Tonle Sap Lake.
\end{abstract}

Keywords: river-lake relationship, reverse flow, backflow intensity, water level difference

\section{Introduction}

Lancang-Mekong River is the most important transboundary river in Asia that runs through six countries including China, Myanmar, Laos, Thailand, Cambodia and Vietnam. It stretches over a total of $4880 \mathrm{~km}$ and drains an area of $812400 \mathrm{~km}^{3}$ (Royal et al., 2010; Mekong River Commission, 2011). The main stream of Mekong River is connected to the Tonle Sap Lake - the largest freshwater lake in Southeast Asia (with an annual average level of water at $4.64 \mathrm{~m}$, covering an area of $6177 \mathrm{~km}^{2}$ and a volume of 15.1 billion $\mathrm{m}^{3}$ ) via the Tonle Sap River in Phnom Penh. The Lancang-Mekong River basin is shown in Figure 1.

Tonle Sap Lake closely resembles the Poyang Lake, China's largest freshwater lake, because they are both seasonal freshwater lakes with water flowing in and flowing out. Besides, Yangtze River connects with Poyang Lake at Hukou, and Mekong River connects with Tonle Sap Lake at Phnom Penh, giving rise to a complicated and worldfamous river-lake relationship where the water of the lake drains into the river or the water in the river flows back to the lake (Cochrane et al., 2014; Luo et al., 2008; Hu et al., 2011; Fang et al., 2012). So far, there have been many systematic studies on the correlation between Yangtze River and Poyang Lake (Huo, 2011; Zhong et al., 2008; Yin et al., 2007; Hu et al., 2007; Dai et al., 2015; Zhang et al., 2014, 2015; Guo et al., 2012), and the conclusions show that the river-lake relationship has complicated internal mechanisms which are demonstrated in several ways including the main stream's drainage capacity, the river-connected-lake channel's capacity to diverge flows and discharge sediments, as well as the lake's flood control capacity. Among the few studies on the relationship between Mekong River and Tonle Sap Lake (Mekong River 
Commission, 2005; Republic of Korea et al., 2008), most of them focus on the time and volume of the reverse flow from Mekong River to Tonle Sap Lake or analyze the balance between the inflow and outflow of water in Tonle Sap Lake. However, there are no in-depth studies on the variation characteristics of duration and volume of the reversal flow, and research on factors influencing the reversal flow and related hydrological conditions is also absent. Therefore, it is advisable to make full use of the latest research achievements on the correlation between Yangtze River and Poyang Lake to probe into the correlation between Mekong River and Tonle Sap Lake while giving due attention to the differences between Poyang Lake and Tonle Sap Lake.

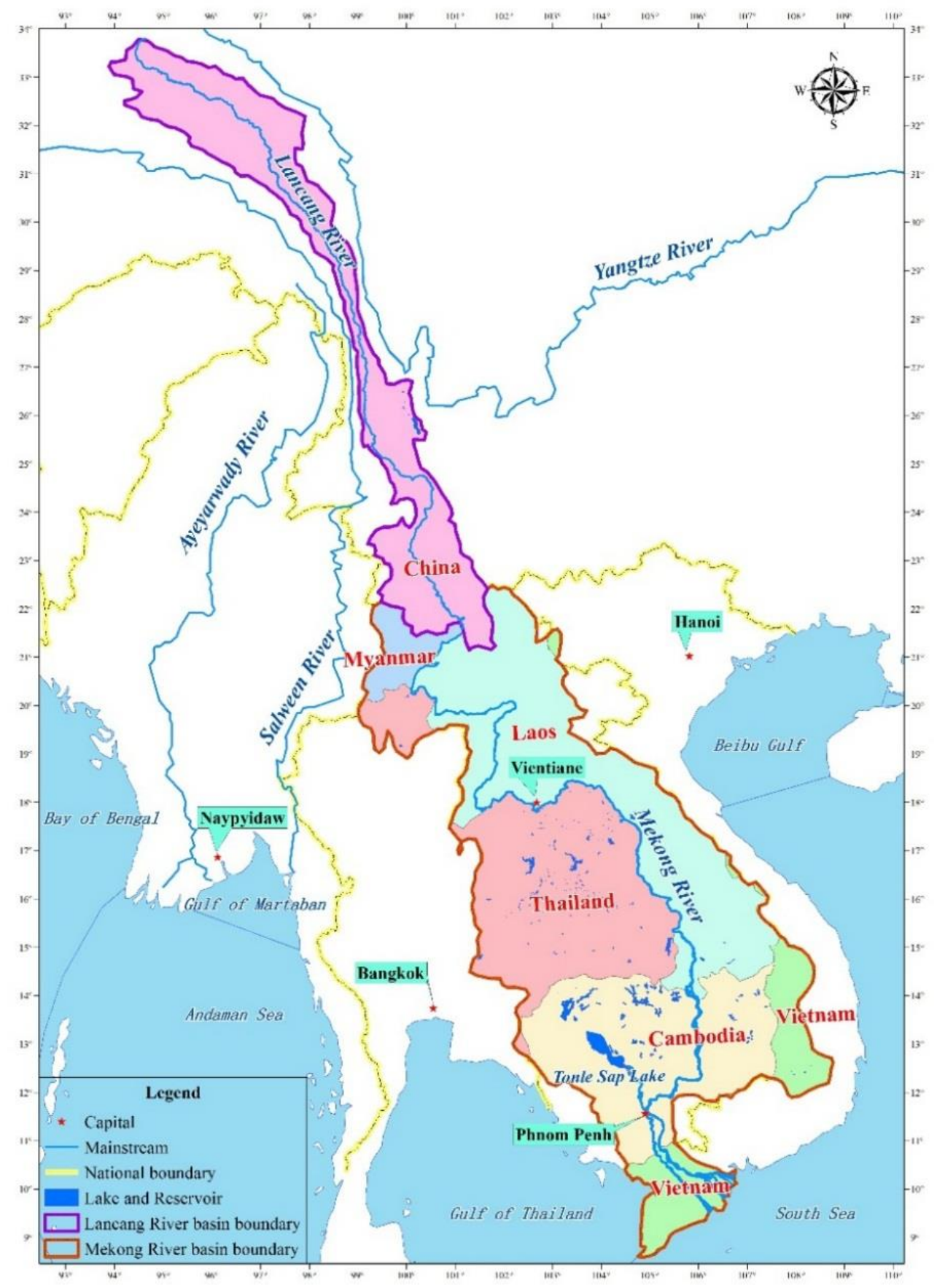

Figure 1. Watershed map of Lancang-Mekong River 


\section{Salient geomorphic differences}

Poyang Lake is a lake when the water level is high, but it resembles a river when the water level is low, creating a unique landscape of a wide stretch of lake in the flood season while a narrow watercourse in the dry season. The maximum surface area of the lake $\left(3708 \mathrm{~km}^{2}\right)$ accounts for $2.29 \%$ of the area of the whole basin $\left(162200 \mathrm{~km}^{2}\right)(\mathrm{Mak}$ et al., 2012; Changjiang Institute of Survey, Planning, Design and Research, 2015; You et al., 2013; Li et al., 2018a). In contrast, the terrain of Tonle Sap Lake is plain; the average gradients for the outlet watercourse of Tonle Sap Lake, the lake area and the watercourse of Tonle Sap River are 0.0988\%o, 0.0024\%o and 0.0354\%o, respectively. The water surface gradient is mild, which averages at $0.0062 \%$ and reaches its maximum at $0.0189 \%$. The maximum surface area of the lake equals approximately $17.75 \%$ of the total area of the basin $\left(86000 \mathrm{~km}^{2}\right)$, thus Tonle Sap Lake retains the appearance of a lake both in the flood and the dry seasons. As Tonle Sap Lake is situated in a plain, its difference of water level, surface area and volume in flood and dry seasons fall below those of Poyang Lake. In the case of Poyang Lake, when it reaches the highest water level at $20.7 \mathrm{~m}$, its surface area reaches $3708 \mathrm{~km}^{2}$ and its volume 30.363 billion $\mathrm{m}^{3}$; when it falls to its lowest water level at $4.01 \mathrm{~m}$, its surface area shrinks to $28.7 \mathrm{~km}^{2}$ and its volume to 63 million $\mathrm{m}^{3}$; the ratio of these two extreme surface areas is 129 , and that of the extreme volumes is 482 . In the case of Tonle Sap Lake, when it reaches the highest water level at $10.54 \mathrm{~m}$, its surface area is $15261 \mathrm{~km}^{2}$ and its volume is 78.7 billion $\mathrm{m}^{3}$; when it reaches the lowest water level at $1.11 \mathrm{~m}$, its surface area shrinks to $2053 \mathrm{~km}^{2}$ and its volume to 780 million $\mathrm{m}^{3}$; the ratio of the extreme surface areas is 7 and that of the extreme volumes is 101 . The largest surface of Tonle Sap Lake is 4.12 times as large as that of Poyang Lake, and its maximum volume 2.59 times as much as that of Poyang Lake; while its minimum surface area and minimum volume are 71.53 times and 12.38 times the size of Poyang Lake, respectively (Li et al., 2018a). The map of Tonle Sap Lake in different hydrological conditions is shown in Figure 2.

\section{Geomorphic differences in the watercourse}

The mainstream of Yangtze River in Hukou section is located between the upper reaches and the lower reaches of the river. Embankments are built to defend tremendous flood that may occur every two decades, and optimal coordination of the upper stream and the local flood detention-retention basin will meet the requirement to defend a flood resembling that happened in 1954. The mainstream of Mekong River that runs through Phnom Penh is located at the Mekong Delta in Cambodia where a low plain prevails, and the flow discharge capacity of the river in this section is far from enough to handle the enormous flow volume from the upper stream. When the water level of Kompong Cham reaches above $13 \mathrm{~m}$, vast flooding plain of left and right banks in Mekong River are easily inundated through the branch watercourses or irrigation channels, resulting in inundation that lasts an annual average of 19 to 48 days, with an annual average overland flood volume in the floodplain of approximate 42.3 billion $\mathrm{m}^{3}$ (Changjiang Water Resources Commission of the Ministry of Water Resources, 2019).

\section{Different inflow from the mainstream}

The mainstream of Yangtze River in Hukou station has a surface area of 1.68 million $\mathrm{km}^{2}$, accounting for $93 \%$ of the area of the whole basin, and is about 
$338 \mathrm{~km}$ away from the boundary with the lower-stream tidal areas at Datong station. The surface area of the entrance where Tonle Sap River drains into Mekong River is about $749000 \mathrm{~km}^{2}$, accounting for $92 \%$ of the total area of the basin. Aside from the inflow from the upper stream, the mainstream of Mekong at Phnom Penh is also subject to tidal movements in the downstream area. As a result, the flood lasts long in this region and subsides slowly, with an average rate of flood flow at 1.5 to $2.0 \mathrm{~km} / \mathrm{h}$.

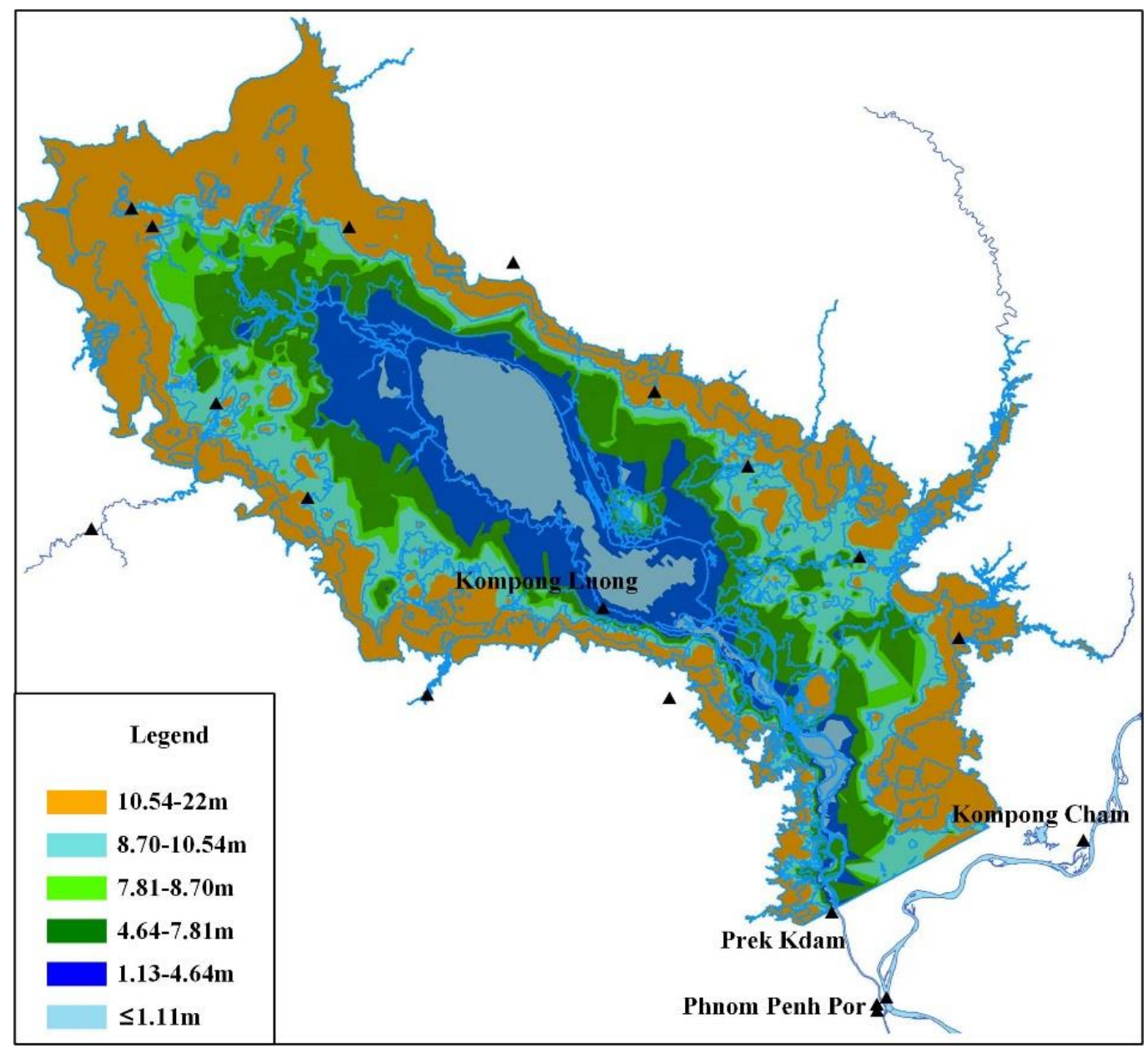

Figure 2. Area distribution of Tonle Sap Lake under different characteristic stage

\section{Different water exchange intensity between Mekong River and Tonle Sap Lake}

Due to conditions of the watercourses, geomorphic features and inflow of water, Tonle Sap Lake is much more capable than Poyang Lake in terms of flood control and water storage ( $\mathrm{Li}$ et al., 2018a, b). The water exchange between Mekong River and Tonle Sap Lake is more frequent and active than that between Yangtze River and Poyang Lake. Every year on average, the reversal flow from Mekong River to Tonle Sap Lake lasts 122 days and the volume of the reverse flow reaches 37.7 billion $\mathrm{m}^{3}$. In contrast, the reversal flow from Yangtze River to Poyang Lake lasts an average of 15 days every year, merely $12 \%$ of that from Mekong River to Tonle Sap Lake, and the annual average volume of the reverse flow is 2.843 billion $\mathrm{m}^{3}$, only $7.5 \%$ of that from Mekong River to Tonle Sap Lake (Li et al., 2018c; Changjiang Water Resources Commission of the Ministry of Water Resources, 2013). 
Poyang Lake accounts for a crucial part in the watershed of Yangtze River and the overall ecological system; likewise, Tonle Sap Lake plays an important part in the watershed of Mekong River and the ecological system. Therefore, it is the key to ensure the ecological health of the river and the lake by fully understanding the correlation between Mekong River and Tonle Sap Lake and providing a scientific basis for river and lake regulation. By referring to the research achievements on the relationship between Yangtze River and Poyang Lake, this study made use of long-series hydrological data of several hydrological monitoring stations on the mainstream of Mekong River (Fig. 2), including the Kompong Cham station, Phnom Penh Port station on Tonle Sap Lake, Prek Kdam Station and Kompong Luong Station, to analyze the characteristics of changes in water volume, influencing factors and hydrological conditions of the reverse flow from Mekong River to Tonle Sap Lake. Here, the Kompong Cham station is similar to Jiujiang Station on Yangtze River, the Phnom Penh Port station is a stream gauging station, which is similar to Hukou station on Poyang Lake, the Prek Kdam Station is a hydrological station, which is similar to Xingzi Station on Poyang Lake in terms of the water-level monitoring location, but similar to Hukou Station on Poyang Lake in terms of the flow monitoring location, the Kompong Luong Station is also a stream gauging station, which is similar to Duchang Station on Poyang Lake.

The objectives of this study were as follows: 1) characterize the variation of duration and volume of reversal flow from Mekong River to Tonle Sap Lake; 2) identify the major factors of reversal flow; 3) analyze the hydrological conditions of reversal flow.

It is expected to facilitate an in-depth understanding of the interactive mechanism between Mekong River and Tonle Sap Lake, and provide a scientific basis for the integrated treatment of Tonle Sap Lake, thereby better understand the interactive mechanism between Yangtze River and Poyang Lake.

\section{Materials and methods}

\section{Study area}

Tonle Sap Lake basin is situated on the Cambodia Mekong Delta, and covers a total area of $81,763 \mathrm{~km}^{2}$. It is the important sub-area within the Lower Mekong Basin due to its complex hydrological and ecological system, rich biodiversities and critical basin development issues (Mak et al., 2012). The Tonle Sap Lake, located at the center of the sub-area as shown on Figure 3, is the largest permanent freshwater lake in Southeast Asia. The Lake is connected to the Mekong through the Tonle Sap River at Chaktomuk conjunction in Phnom Penh, about $120 \mathrm{~km}$ to the southwest outlet of the Lake. The lake is $371 \mathrm{~km}$ long, with an area of around $2,744 \mathrm{~km}^{2}$ in the dry season and during the wet season it can swell to four or seven times this area. The most prominent feature of the sub-area is the Tonle Sap Lake with its interesting hydrological and ecological functions for the whole Mekong River basin. The water flow of the Tonle Sap River and lake is closely related to the hydrological performance of the Mekong River. The lake discharges water (out-flow), through the Tonle Sap River, into the Mekong River during the dry season. During the wet season, however, the Mekong River becomes bloated by run-off, thus forces the Tonle Sap River to reverse its flow direction (from out-flow to in-flow), filling the lake instead of draining it. The inflow inundates the surrounding forested floodplains, and supports the rich biodiversity of the lake eco-system. 


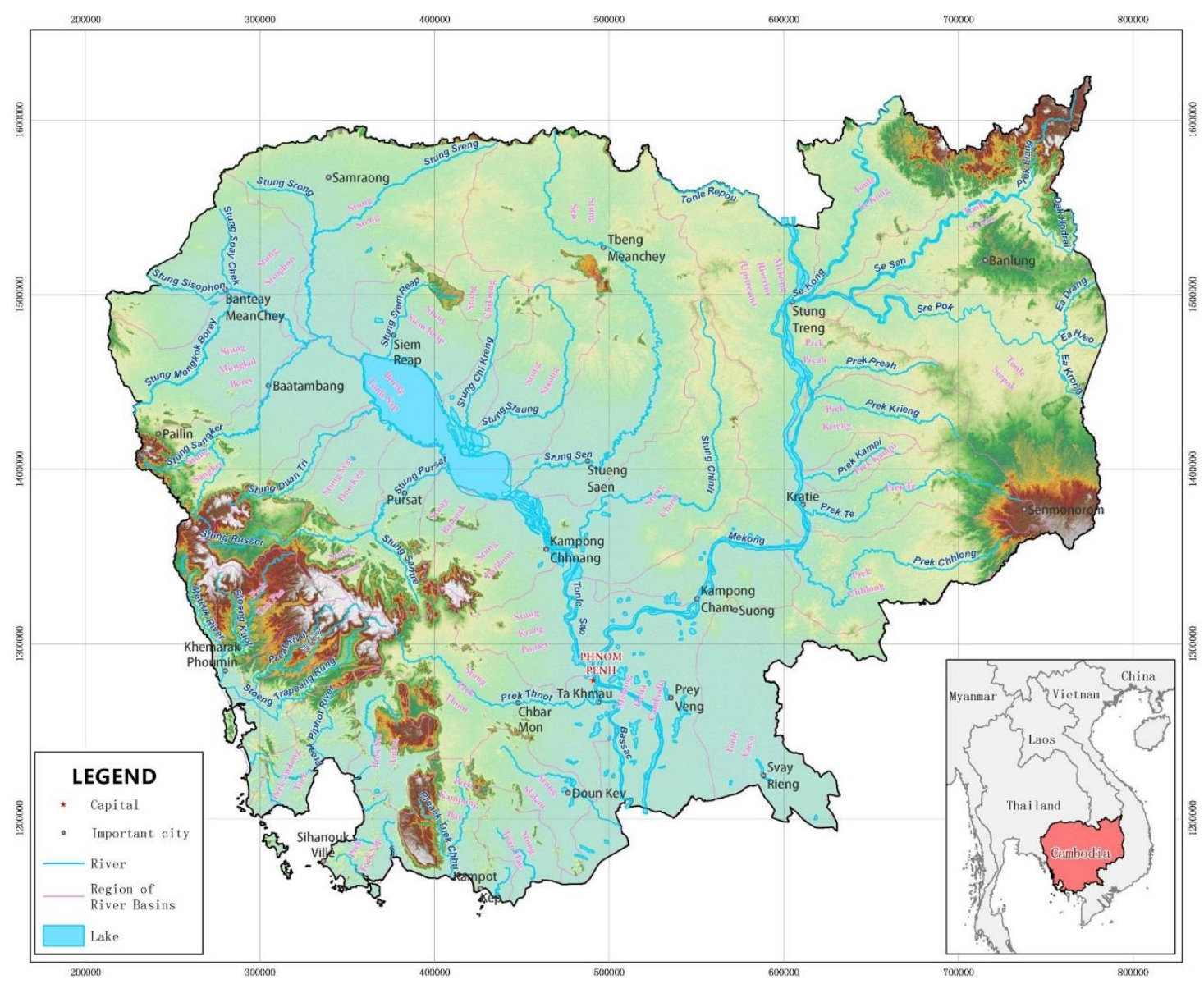

Figure 3. Map of River Basin in Cambodia

\section{Hydrological stations and data collection}

There are are four controlling hydrological stations installed on the Tonle Sap Lake Area and Cambodia Mekong Delta, namely, Kompong Cham Station, Phnom Penh Port Station, Prek Kdam Station and Kompong Luong Station, as shown in Figure 2. Among them, Kampong Cham Station is located at the mainstream of Mekong River, with a distance of around $103 \mathrm{~km}$ from the exit of Tonle Sap River and a catchment area of $660,000 \mathrm{~km}^{2}$ which accounts for $81 \%$ of the total area of the whole basin; Phnom Penh Port Station is located at the end of the Tonle Sap River, with a distance of about $1 \mathrm{~km}$ from the exit of Tonle Sap River, so it can be used as the water level representative station at the intersection of the Mekong River and the Tonle Sap River; Prek Kdam Station is the inflow-outflow controlling station of Tonle Sap Lake, about $32 \mathrm{~km}$ from the exit of Tonle Sap River; Kampong Luong Station is the waterlevel representative station of Tonle Sap Lake, which is about $172 \mathrm{~km}$ far from the exit of Tonle Sap River.

The hydrological data for the above four river-lake controlling stations collected from Ministry of Water Resources and Meteorology in Cambodia and Mekong River Commission are not homogenous, because not all records started in the same time and/or not all stations have the same number of records. 52 years of daily discharge data from 1960 to 2011 is available for Kompong Cham Station, 58 years of daily water level data from 1960 to 2017 is available for Phnom Penh Port Station, 17 years 
of daily water level data from 1995 to 2011 and 58 years of daily water level data from 1960 to 2017 are available for Prek Kdam Station, and 19 years of daily water level data from 1999 to 2017 is available for Kampong Luong Station.

To ensure the consistency of hydrological analysis, the discharge data with the same period from 1995 to 2011 of Kompong Cham Station and Prek Kdam Station, and the water level data with the same period from 1999 to 2011 of Phnom Penh Port Station, Prek Kdam Station and Kampong Luong Station were used. The water level data uses the Cambodian National Elevation Datum (M.S.L. Hatein datum).

\section{Data analysis}

The inflow from the Mekong River via the Tonle Sap River can be computed from the observed discharge data at Prek Kdam Station. Therefore, the timing of when flow reversal occurs, the variation characteristics of duration and volume of reversal flow, and the ratio of the reverse volume accounts for the total volume of Mekong River at the Kompong Cham Station, which are of importance for the ecological functioning of the Tonle Sap system and wider Lower Mekong River Basin, have been statistically analysed at the Prek Kdam monitoring site. The water level at Phnom Penh Port Station, Prek Kdam Station and Kampong Luong Station and a correction for backwater based on the water level difference between Phnom Penh Port and Kampong Luong were used to identify the major factors and hydrological conditions of reversal flow from Mekong River to Tonle Sap Lake.

\section{Results}

\section{Time series variation characteristics of reversal volume}

According to measured flow records from 1995 to 2011 at the Prek Kdam station, this study concluded the duration and volume of reverse flow from Mekong River to Tonle Sap Lake during flood seasons, as shown in Figures 4 and 5. It can be seen that the flow reversal from Mekong River to Tonle Sap Lake occurs every year, and the reverse flow duration is long and reversal volume is large. On average, it lasts 122 days and reaches 37.7 billion $\mathrm{m}^{3}$ in volume every year. The reversal occurs from May to October, especially from July to September - these three months account for $71 \%$ of the whole time and $88.6 \%$ of the total amount of reversal in a year. The reversal usually reaches its maximum in August during which flow reversal happens every day and reaches an annual average volume of 16.2 billion $^{3}$, making up $43 \%$ of the yearly total.

According to Figure 4, the longest duration of backflow lasted 149 days in 1999, and the shortest lasted 73 days in 1995, with a variation amplitude of 76 days and a variation coefficient of 0.14 . The maximum annual reversal volume is 49.6 billion $\mathrm{m}^{3}$ in 2005 and the minimum is 21.3 billion $\mathrm{m}^{3}$ in 1998, with a variation amplitude of 28.3 billion $\mathrm{m}^{3}$ and a variation coefficient of 0.24 . The annual average of flood peak flow from Mekong River was $8402 \mathrm{~m}^{3} / \mathrm{s}$, with the maximum at $10679 \mathrm{~m}^{3} / \mathrm{s}$ in 1997 and the minimum at $4584 \mathrm{~m}^{3} / \mathrm{s}$. Thus, the maximum/minimum ratio of flood peak flow and annual volume were both 2.33 . In general, the reversal duration and volume increased slightly year by year, with the average reversal duration increased by one day per year, and the average reversal volume increased by 365 million $\mathrm{m}^{3}$ per year. 


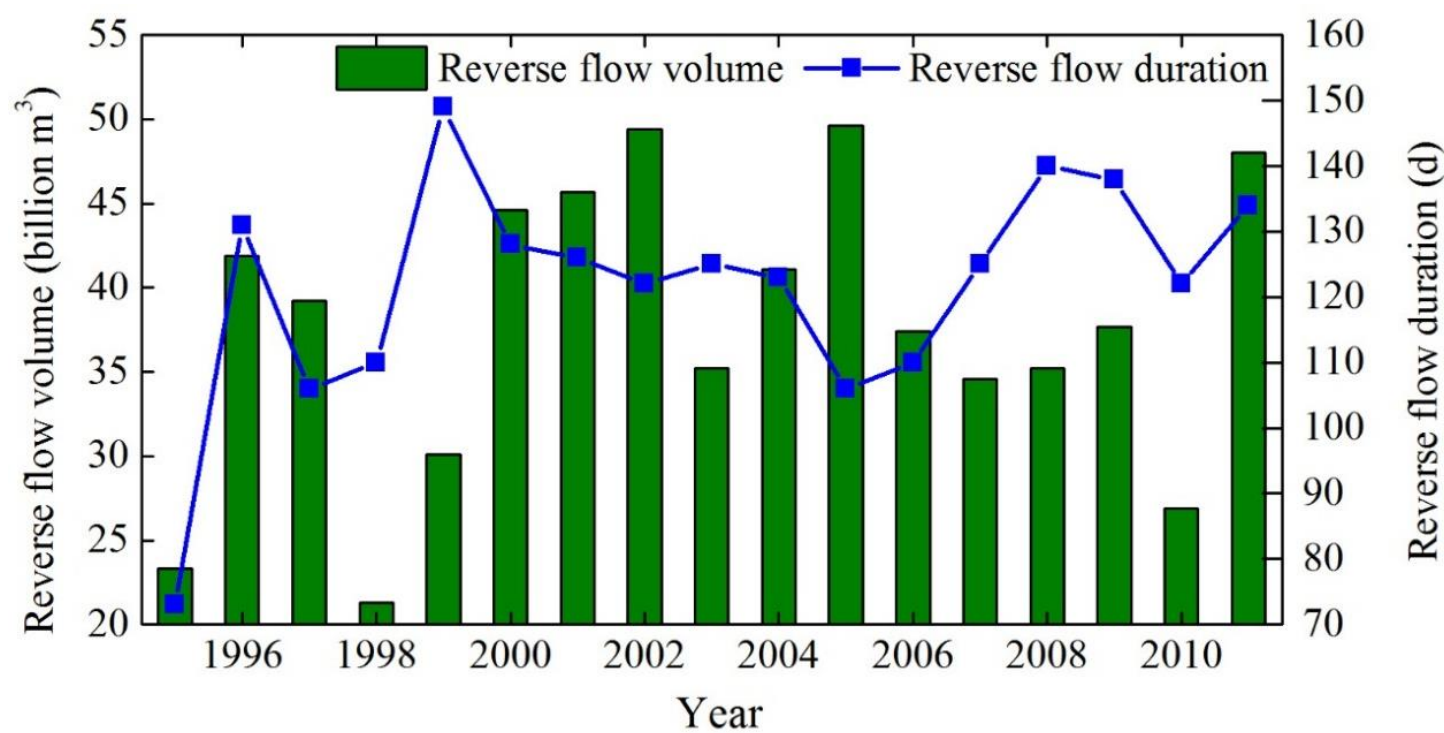

Figure 4. Inter-annual variation of reverse flow duration and volume from Mekong River to Tonle Sap Lake

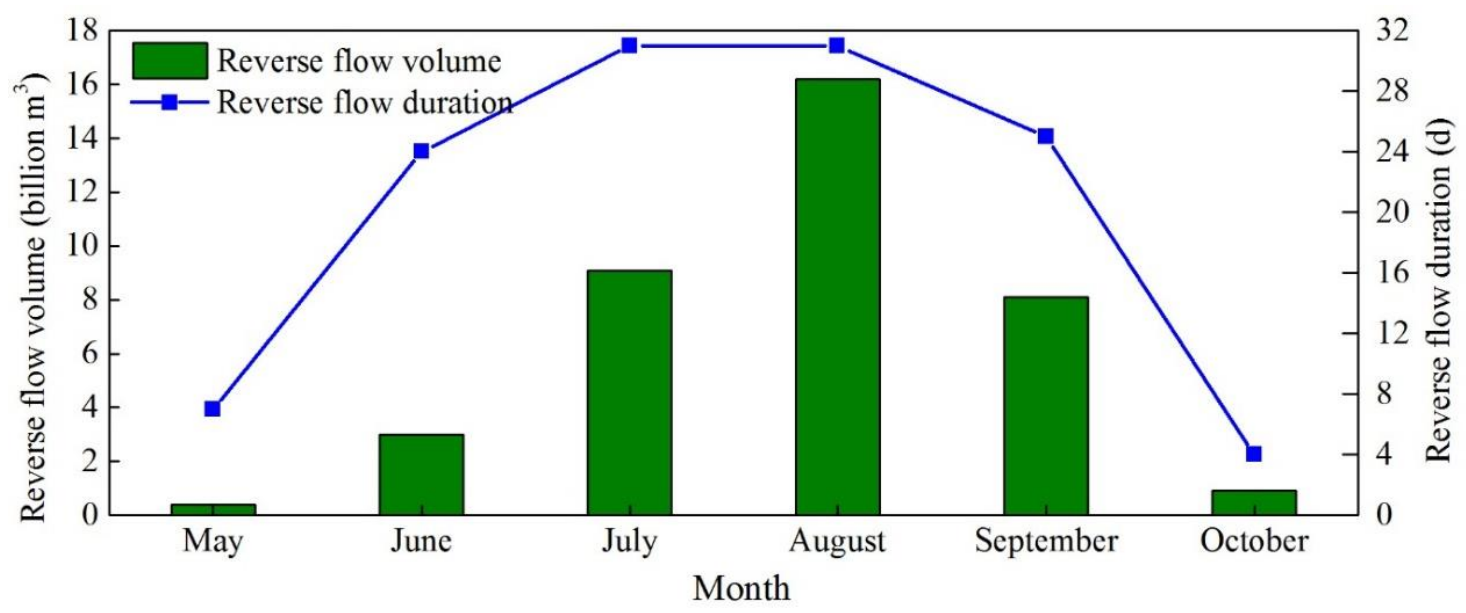

Figure 5. Annual distribution of reverse flow duration and volume from Mekong River to Tonle Sap Lake

\section{Proportion of reverse volume to total volume from Mekong river in the same period}

According to flood statistics from 1995 to 2011, this study achieved the ratio of the reverse volume against the total volume from Mekong River at the Kompong Cham station, as shown in Figure 6. By means of reversal flow, Tonle Sap Lake regulates and stores $10 \%$ to $18 \%$ (averaged at 14\%) of the total flood volume of Mekong River in the flood season. The diversion percentage reaches the peak in August at 17.7\%, followed by July (16.6\%), June (13.2\%), September (10.5\%), May (8.9\%) and October $(8.5 \%)$. When the backward flow reaches the peak, the Tonle Sap Lake reduces the flood peak discharge of Mekong River by $15 \%$ to $24 \%$, averaged at $20 \%$ over the from 1995 to 2011. Overall, the annual variation of the proportion of reverse volume to total volume from Mekong River in the same period is not obvious, and it is slightly increasing. 


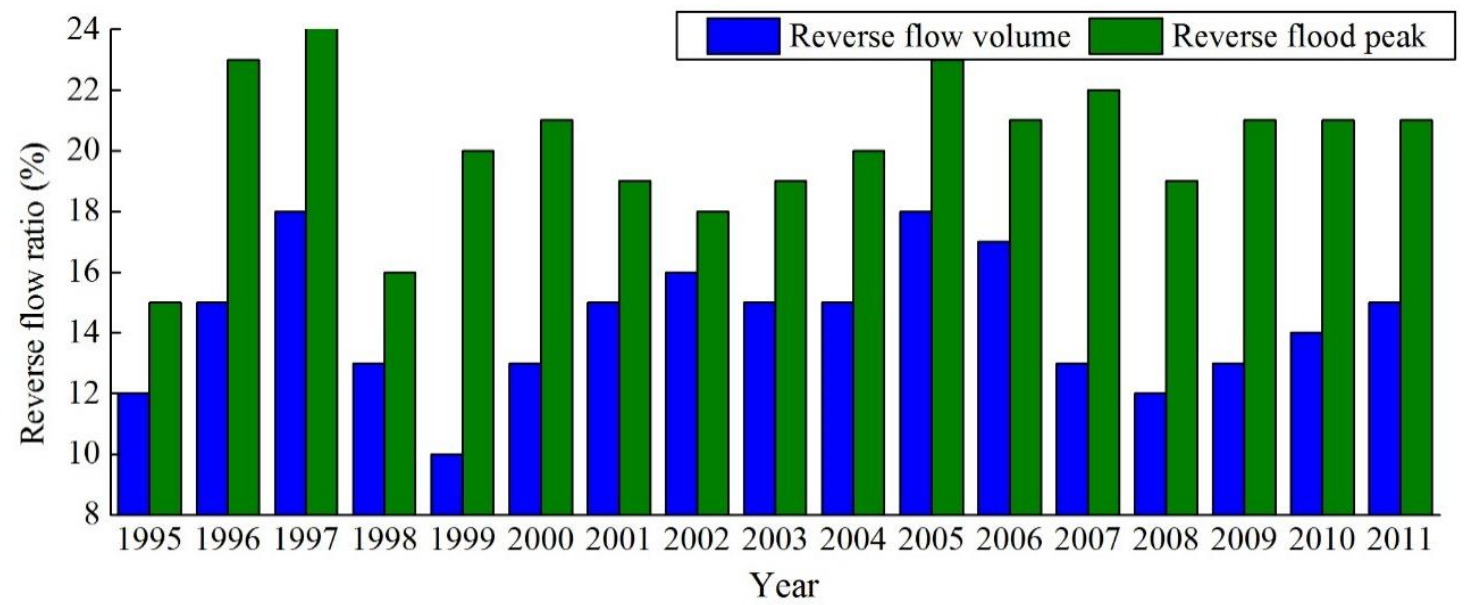

Figure 6. The ratio of reverse flow volume in flood season accounting for Mekong River runoff in the same period

\section{Discussion}

\section{Influencing factors of reversal flow}

The factors that affect the reversal flow from Mekong River to Tonle Sap Lake include the inflow of Mekong River, incoming water from the tributaries of Tonle Sap Lake, runoff difference (or water level difference) between Mekong River and Tonle Sap Lake, tidal water level difference at the beginning of flood season, etc.

\section{(1) Runoff of Kompong Cham Station in Mekong River}

According to the observation data in the flood season (May - October) from 1995 to 2011, the correlation between the flood runoff of Kompong Cham Station in mainstream of Mekong River and reversal flow volume is shown in Figure 7. It can be seen that the correlation is scattered, indicating that the flood runoff of the Mekong River is not a decisive factor of reversal flow.

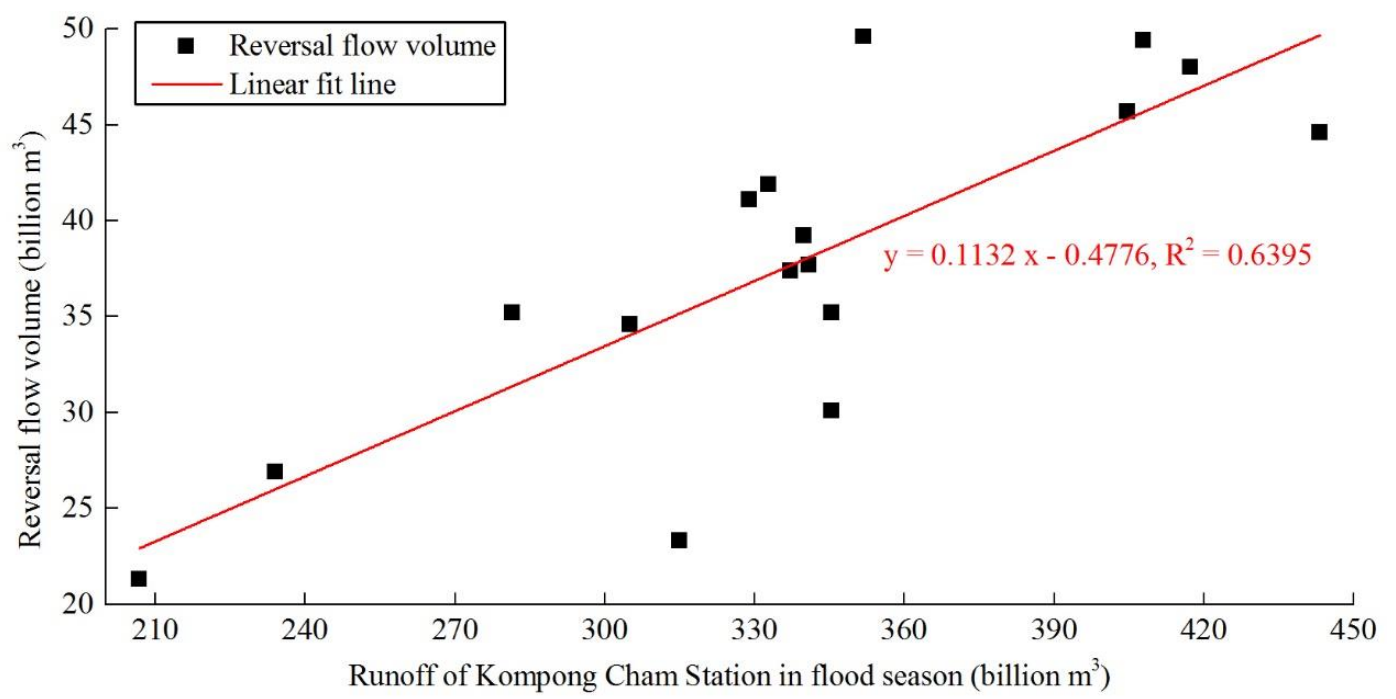

Figure 7. Correlation between the flood runoff of Kompong Cham Station in mainstream of Mekong River and reversal flow volume 
The flow of Kampong Cham Station at the main stream of Mekong River when the flow reversal of Tonle Sap River occurs is shown in Figure 8. It can be seen that when the flow of Kampong Cham Station is above $3000 \mathrm{~m}^{3} / \mathrm{s}$, the phenomenon of backflow may occur. Among them, the probability of backflow is the largest when the flow of Kampong Cham Station is from 10000 to $40,000 \mathrm{~m}^{3} / \mathrm{s}$, which accounts for $67.31 \%$ of the total days of backflow. The reversal flow increases with the rise of the flow of Kampong Cham Station, but the correlation between them is scattered. In May when the runoff of Mekong River is small, the probability and flow of backflow are the minimum, with average annual reverse duration of only 7 days and reverse flow of $471 \mathrm{~m}^{3} / \mathrm{s}$. From June to July, the runoff of Mekong River has increased significantly, and the probability and flow of backflow increased accordingly, with average annual backflow duration of 24 days and 31 days respectively, and average reverse flow of $1286 \mathrm{~m}^{3} / \mathrm{s}$ and $3407 \mathrm{~m}^{3} / \mathrm{s}$ respectively. In August, the runoff of Mekong River above Phnom Penh reaches the peak, which accounts for $21.0 \%$ 23.1\% of the annual runoff, makes the reversal probability and backflow reach the maximum, the backflow has occurred in the whole month, and the average reversal flow is $6049 \mathrm{~m}^{3} / \mathrm{s}$. From September to October, with the increase of inflow from the tributaries of Tonle Sap Lake (reaches its peak) and the decrease of runoff from Mekong River, the probability of backflow and the reversal flow began to decline, with average backflow time of 25 days and 4 days, and average reverse flow of $3775 \mathrm{~m}^{3} / \mathrm{s}$ and $2392 \mathrm{~m}^{3} / \mathrm{s}$, respectively.

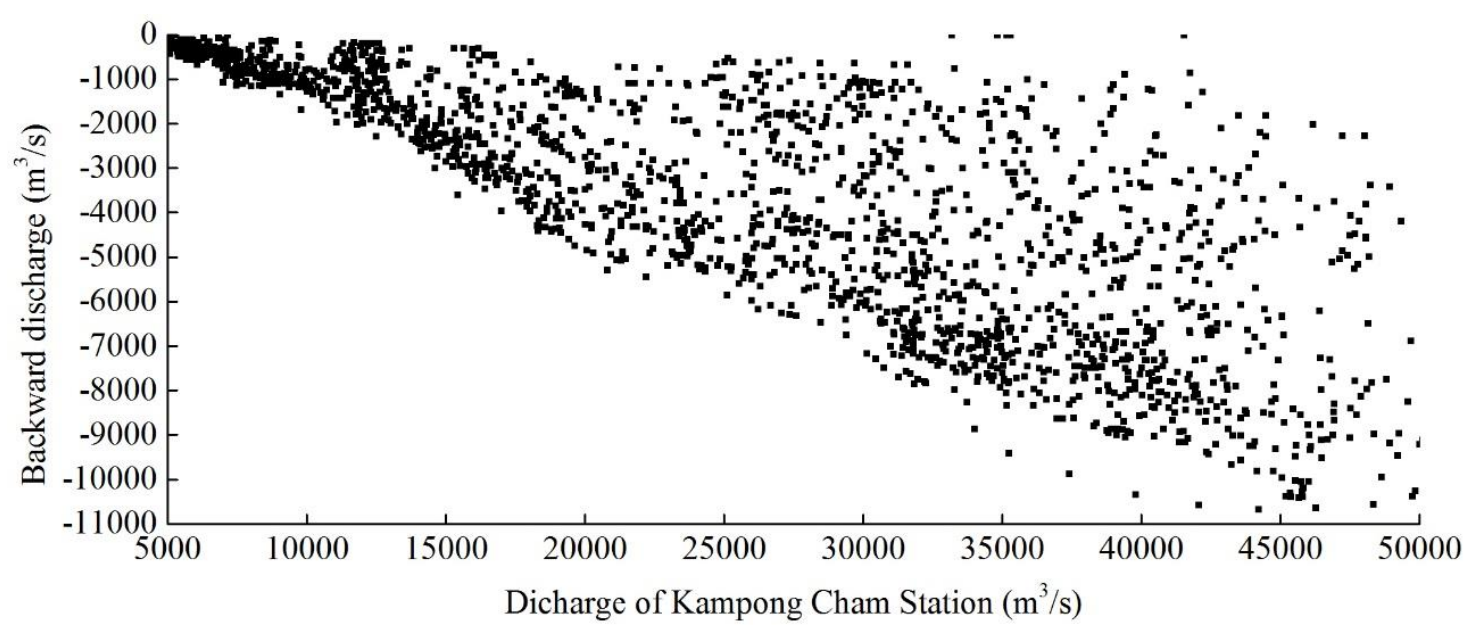

Figure 8. The flow of Kampong Cham Station when the flow reversal of Tonle Sap River occurs

Figure 9 compares the average daily runoffs between the Kompong Cham station on Mekong River and the Prek Kdam station on Tonle Sap River during the flood season from June to September in multiple years from 1995 to 2011. It shows that the volume of reversal flow increases with the increase of discharge from the Mekong River (expressed by the rate of increase) and has little connection with the rate of flow of Mekong River.

\section{(2) River-lake runoff difference}

Figure 10 compares the discharge from Mekong River and that from Tonle Sap Lake for multiple years from 1995 to 2011. It shows that the ratio of discharge of Mekong River against that of Tonle Sap Lake reaches the peak in August (15:1), followed by 
July (11:1), September (10:1) and June (8:1), October (7:1) and May (5:1). The volume of reverse flow follows the same order in time (i.e. August marks the maximum and May the minimum), which implies the influence of the difference in the runoff between Mekong River and Tonle Sap Lake on the volume of the reverse flow.

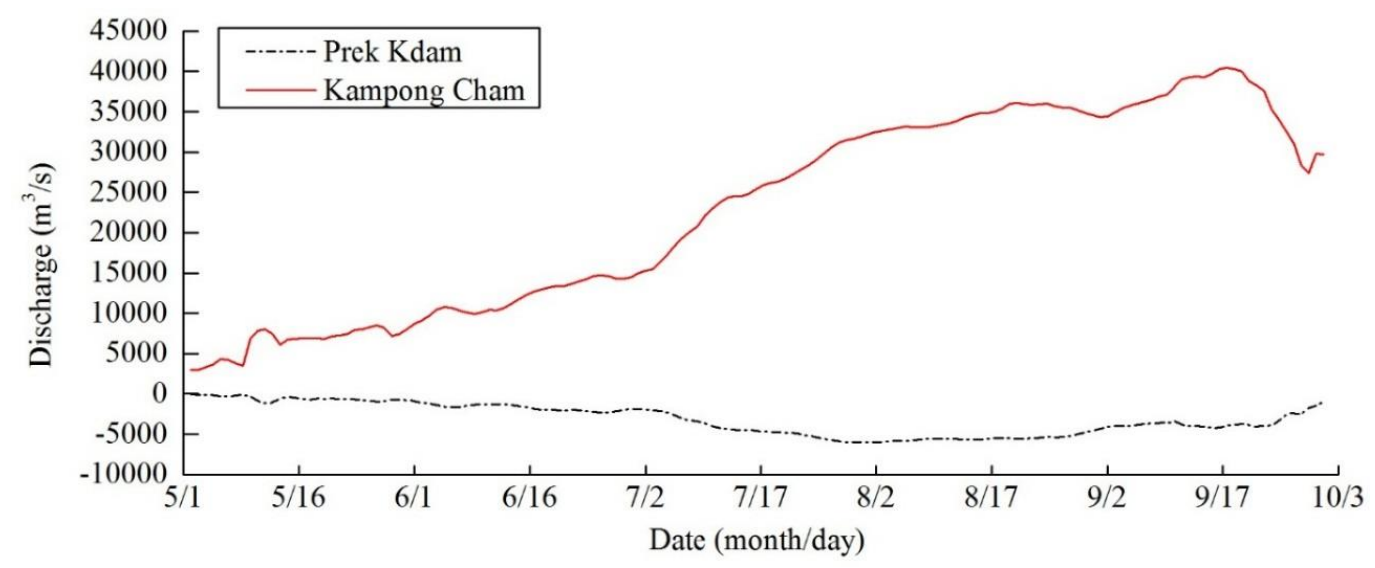

Figure 9. Multi-year average daily discharge of Prek Kdam station and Kompong Cham station in reversal flow season

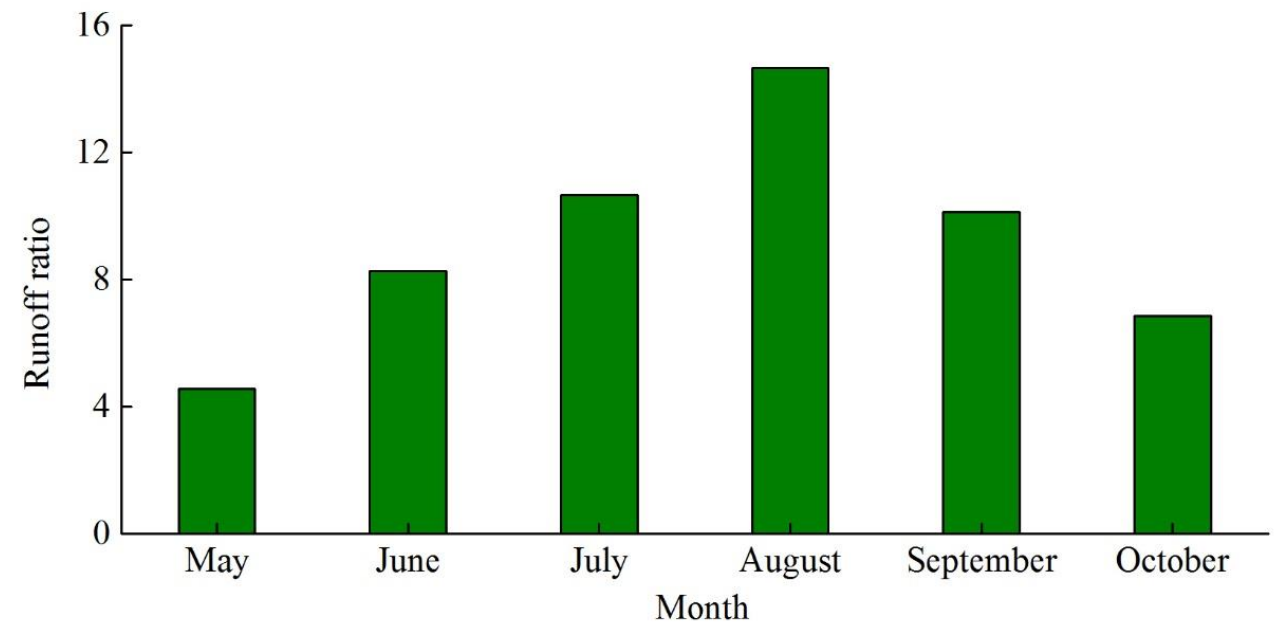

Figure 10. Monthly runoff ratio between Mekong River and Tonle Sap Lake

The deviation (the annual value - the average value of the years from 1995 to 2011) of the runoff difference between Kampong Cham Station in Mekong River and Tonle Sap Lake area during the flood season and the deviation of backwater volume were compared and shown in Figure 11. It can be seen that in 2001, 2002, 2005 and 2011, the runoff of Mekong River in flood season is abundance, and that of Tonle Sap Lake area is dry, so the backwater volume in each year is more than the average annual value; the runoff of Mekong River in 2006 and 2007 is dry, and that of Tonle Sap Lake area is abundance, so the backwater volume is less than the average annual value. In general, the amount of backwater is basically corresponding to the river-lake runoff difference, except for the partial years, which indicates that the reverse flow is not only related to the inflow from Mekong River and Tonle Sap Lake, but also affected by other factors. 


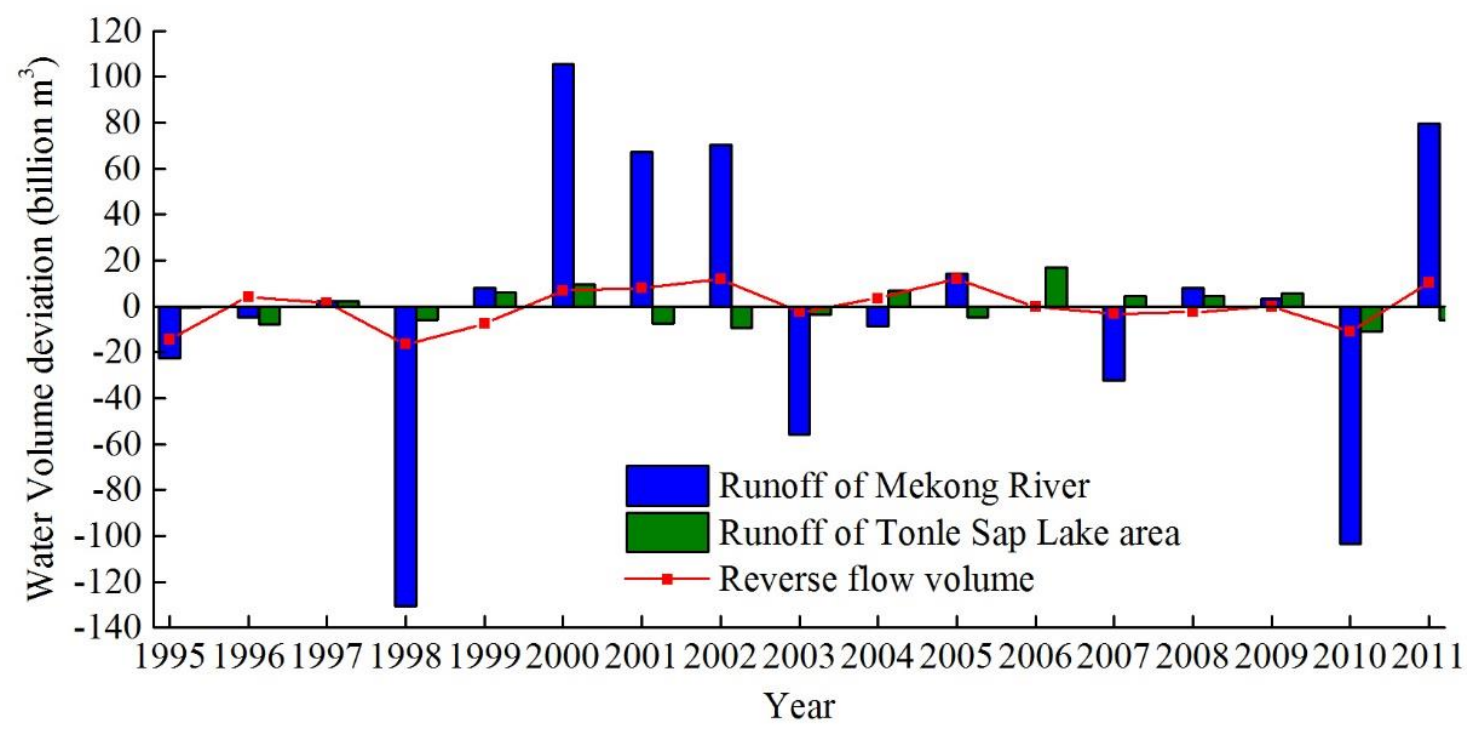

Figure 11. The deviation comparison between river-lake runoff difference and backwater volume during the flood season

\section{(3) River-lake water level difference}

The water level of Phnom Penh Port, Prek Kdam and Kampong Luong stations in the Tonle Sap Lake area in 2001 is shown in Figure 12. It can be seen that when the flood of Mekong River backward flows into the Tonle Sap Lake, the water levels of the above three stations are successively lowered from the bottom to the upper, indicating that the water level difference between Mekong River and Tonle Sap Lake is one of the conditions for the reversal flow of Mekong River.

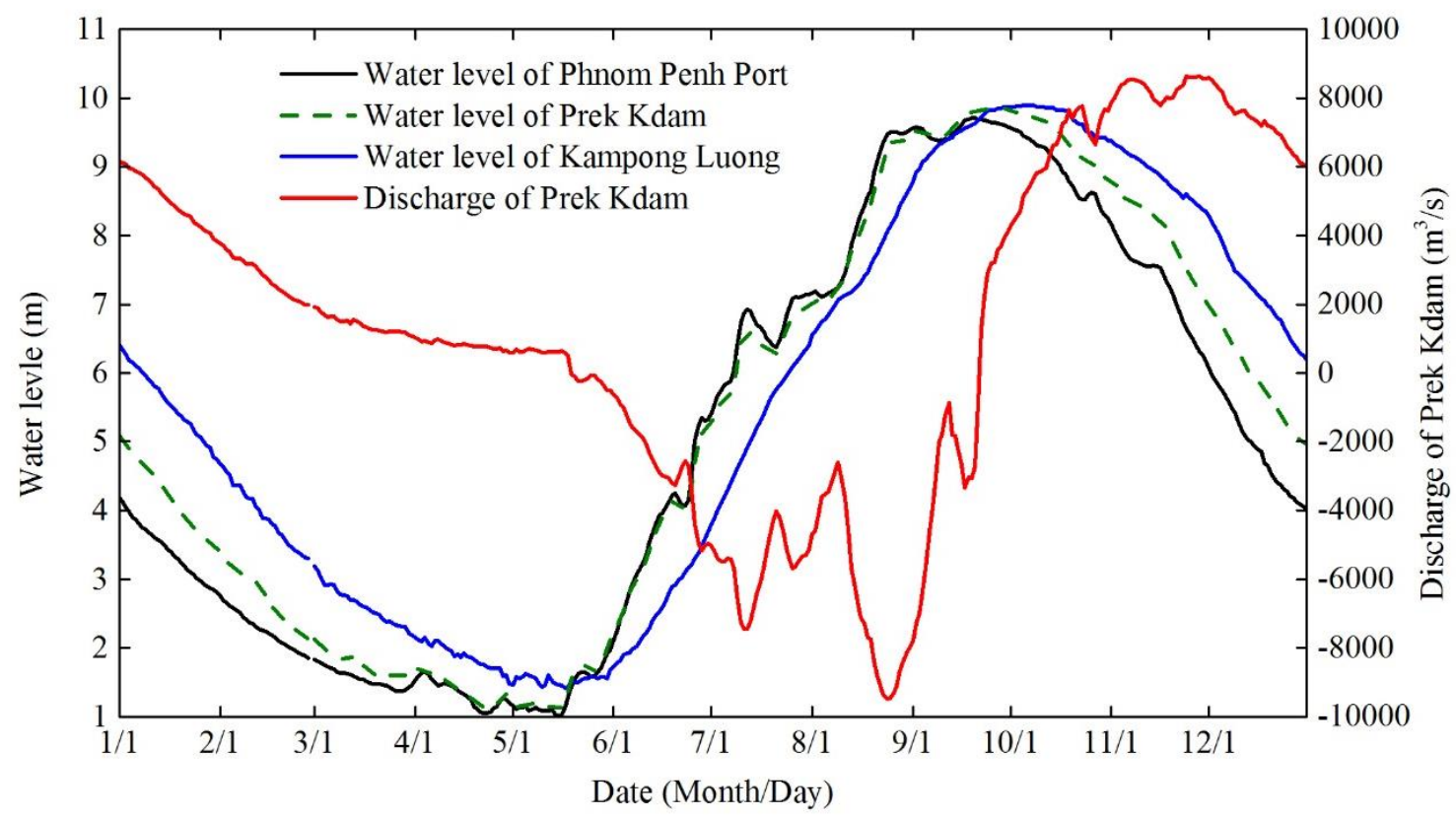

Figure 12. Water level process in 2001 of hydrological stations in Tonle Sap Lake area 
According to long-series statistics of the daily water level obtained from major monitoring stations, the water level during the flood season in Mekong River changes more frequently than that in Tonle Sap Lake. The annual average increase rate of water-level declines from $0.16 \mathrm{~m} / \mathrm{d}$ at the Kampong Cham station on Mekong River, to $0.09 \mathrm{~m} / \mathrm{d}$ at the Phnom Penh Port station at the Tonle Sap River entrance, $0.08 \mathrm{~m} / \mathrm{d}$ at the Prek Kdam station on Tonle Sap River and $0.06 \mathrm{~m} / \mathrm{d}$ at the Kampong Luong station on the Tonle Sap Lake. It indicates that difference in the level of water between Mekong River and Tonle Sap Lake, when the former is higher than the latter, is the major hydrodynamic force that drives the reversal flow, as shown in Figure 13.

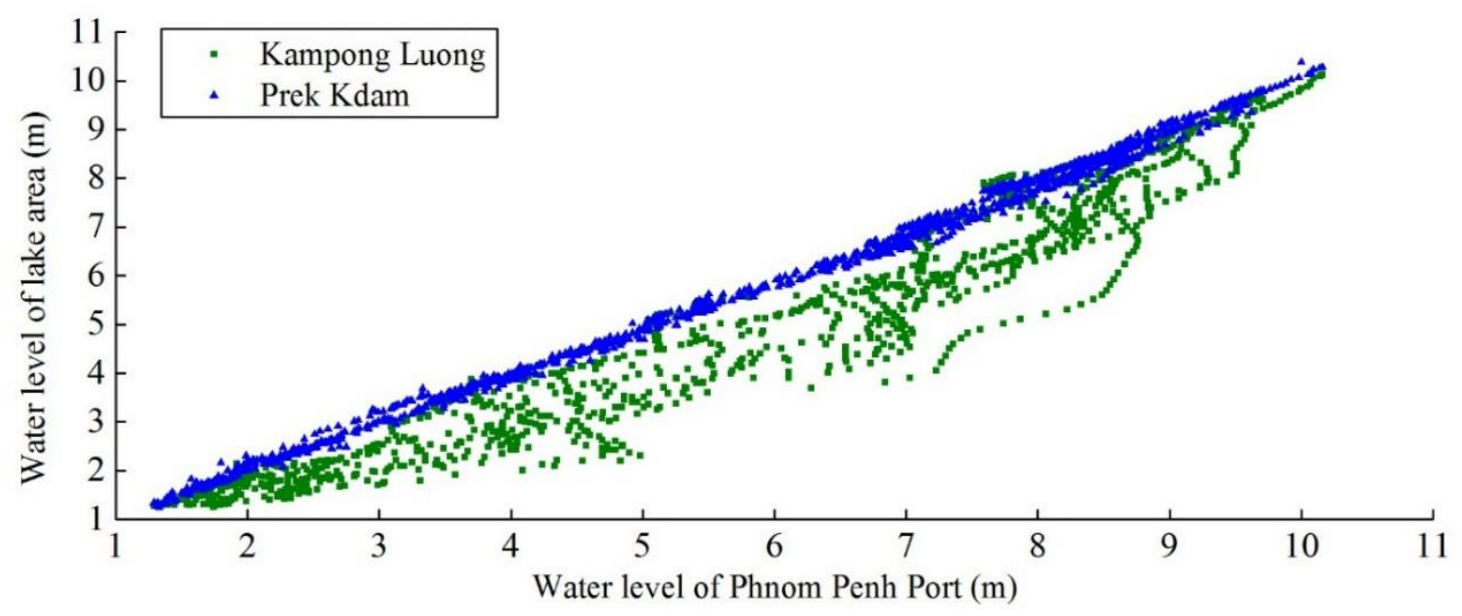

Figure 13. Water level correlation among Prek Kdam station, Kompong Luong station and Phnom Penh Port station

Figure 14 shows the correlation between the reverse flow and the difference in the water level between the river and the lake at the Prek Kdam station. It can be seen that the water level difference between the water level at the Kompong Luong station and the water level at the Phnom Penh station is negative most of the time (92\%), which indicates that difference in the water level is a major contributor to the reversal flow.

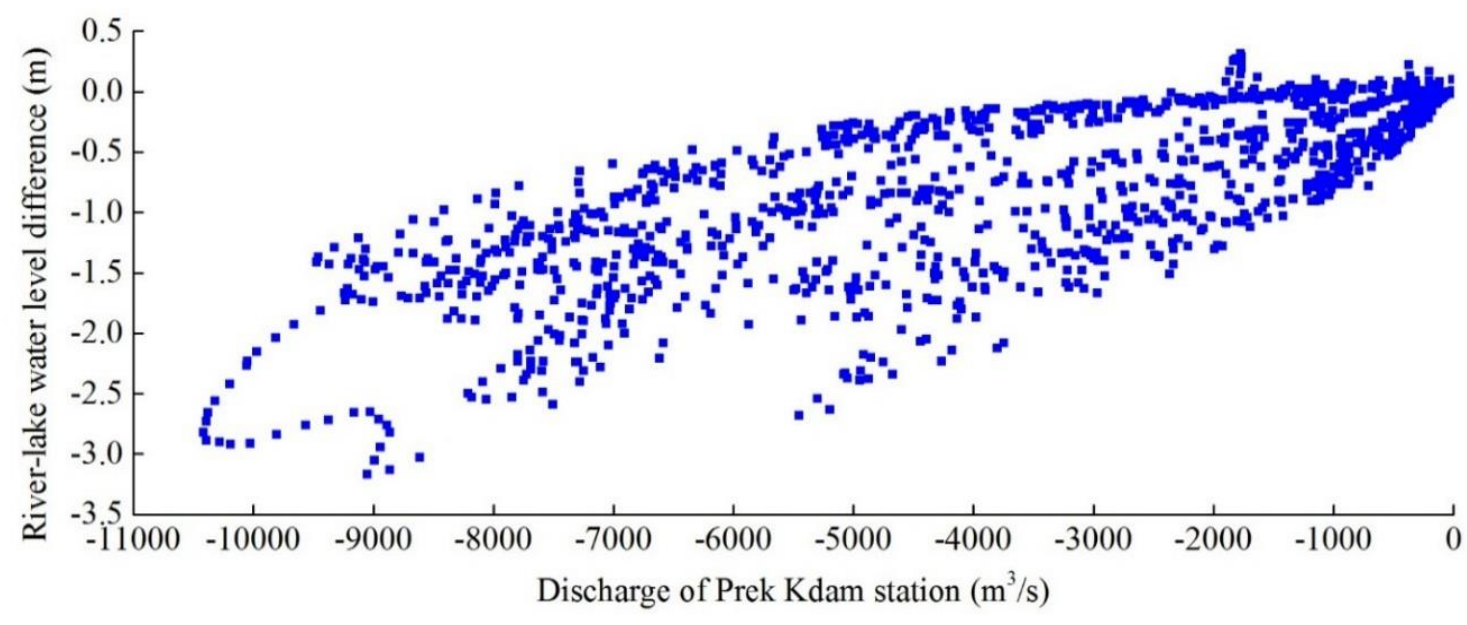

Figure 14. Correlation between discharge and water level difference in Prek Kdam station 
According to statistics, the reverse flow from Mekong River to Tonle Sap Lake increases with the increase of difference in their water levels when the water level at the Prek Kdam remains the same, as shown in Figure 15.

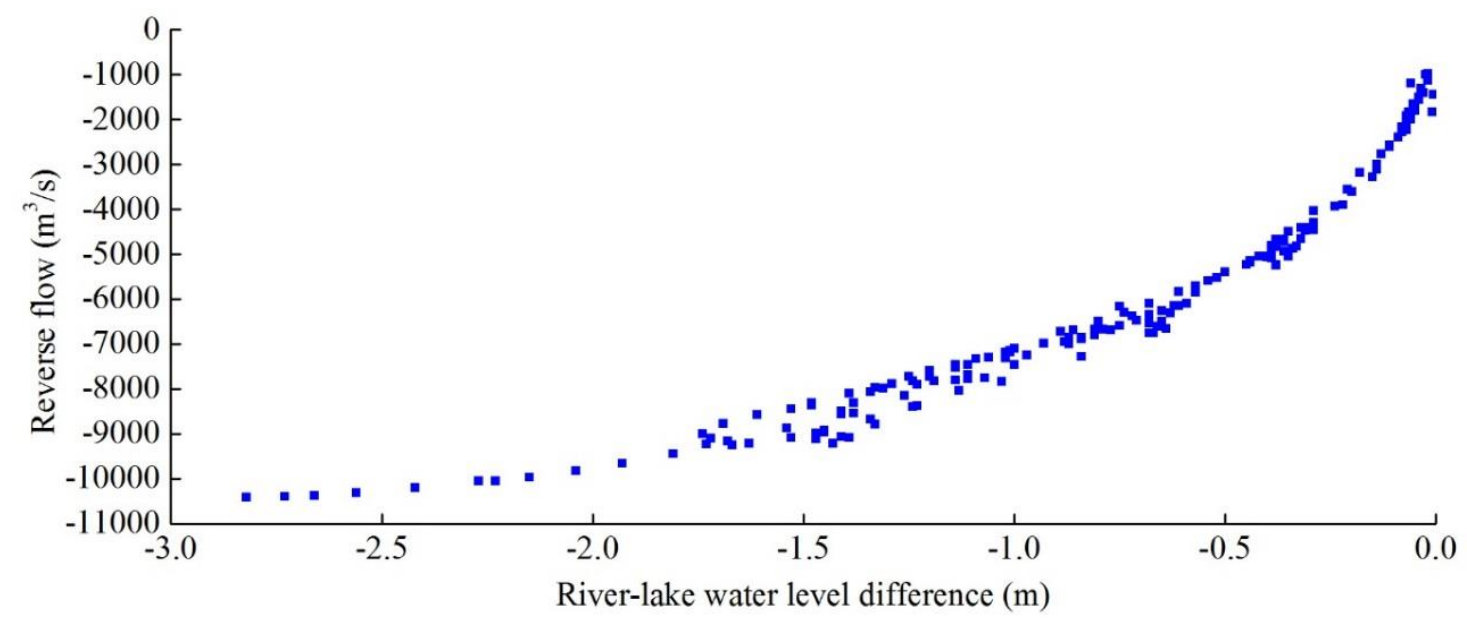

Figure 15. Correlation between backward discharge and water level difference when the water level of Prek Kdam station reaches $8 \sim 9 \mathrm{~m}$

With the difference in the water level between Mekong River and Tonle Sap Lake as the parameter, this study plots a chart of the average daily flow of Tonle Sap River at the Prek Kdam station, the average daily water level of Tonle Sap Lake at the Kompong Luong station and the average daily flow of Mekong River at the Kompong Cham station. The cluster of correlation between the amount of reverse flow and the flow of Mekong River, as well as the correlation between the water level of Tonle Sap Lake and the discharge of Mekong Lake are established according to the center of point groups, as shown in Figure 16. It can be seen that when the difference in the levels of water between Mekong River and Tonle Sap Lake remains constant, the amount of reverse flow increases with the increase of the flow of Mekong River; when the flow of Mekong River remains constant, the volume of reverse flow increases with the increase of difference in the water levels. Therefore, the discharge from Mekong River and the difference in the levels of water are both factors of the reverse flow, and the difference in runoffs directly determines the difference in the levels of water.

\section{(4) Water level of Tonle Sap River}

According to statistics from 1999 to 2011, the reverse flow increases linearly with the rise of water level at the Prek Kdam station when the river-lake water level difference remains constant, as shown in Figure 17. Therefore, the water level of Tonle Sap River accounts for another factor that influences the reversal flow.

\section{(5) Tidal water level difference at the beginning of flood season}

According to the analysis, only the reversal flow at the beginning of the flood period from May to June may be affected by the tides in the South China Sea. The average tidal range is less than $0.2 \mathrm{~m}$, which may result in backflow phenomenon when the daily average water level of Kampong Luong Station in Tonle Sap Lake is higher than that of 
Phnom Penh Port Station in Tonle Sap River. According to the statistics from 1999 to 2011, the phenomenon occurred for 34 days in total for 10 years. Except for the water level difference between Mekong River and Tonle Sap Lake reached $0.29 \mathrm{~m}$ on May 15, 1999, the river-lake water level difference on other dates was less than $0.12 \mathrm{~m}$. The average river-lake water level difference is $0.05 \mathrm{~m}$, and daily average backflow is $147 \mathrm{~m}^{3} / \mathrm{s}$.

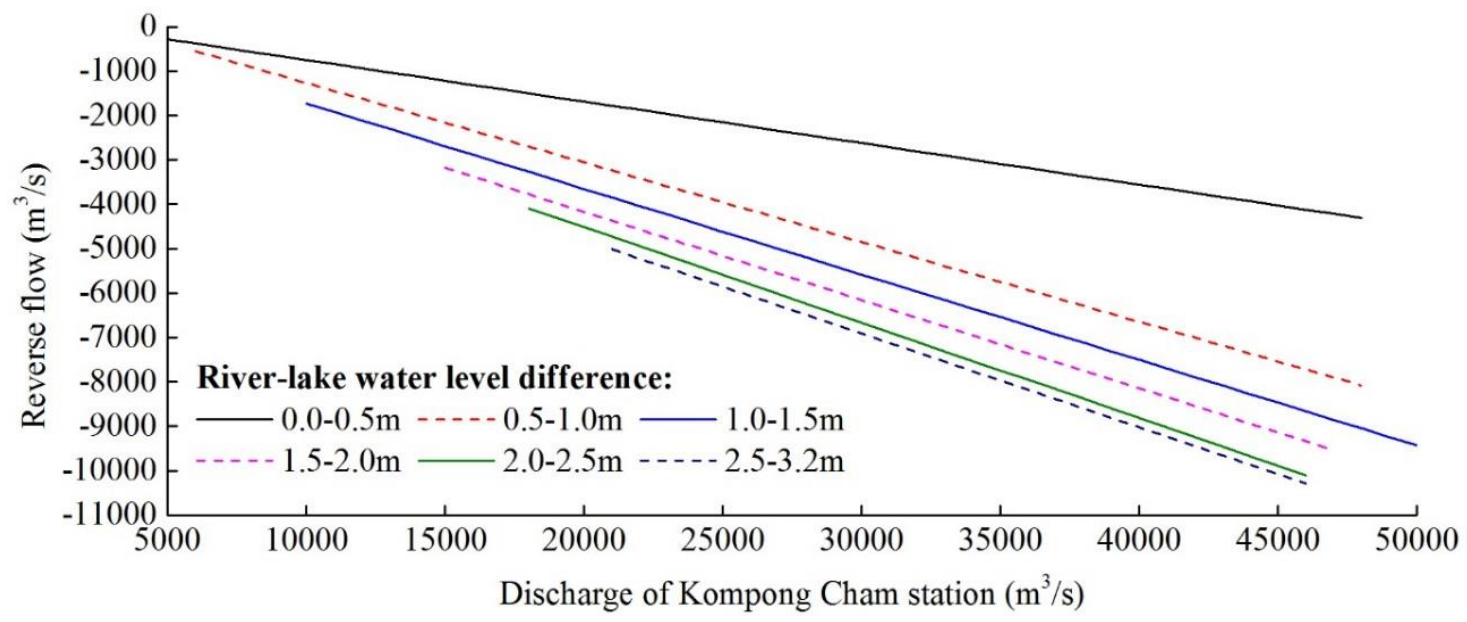

Figure 16. Correlation between the discharge of Prek Kdam station and Kompong Cham station

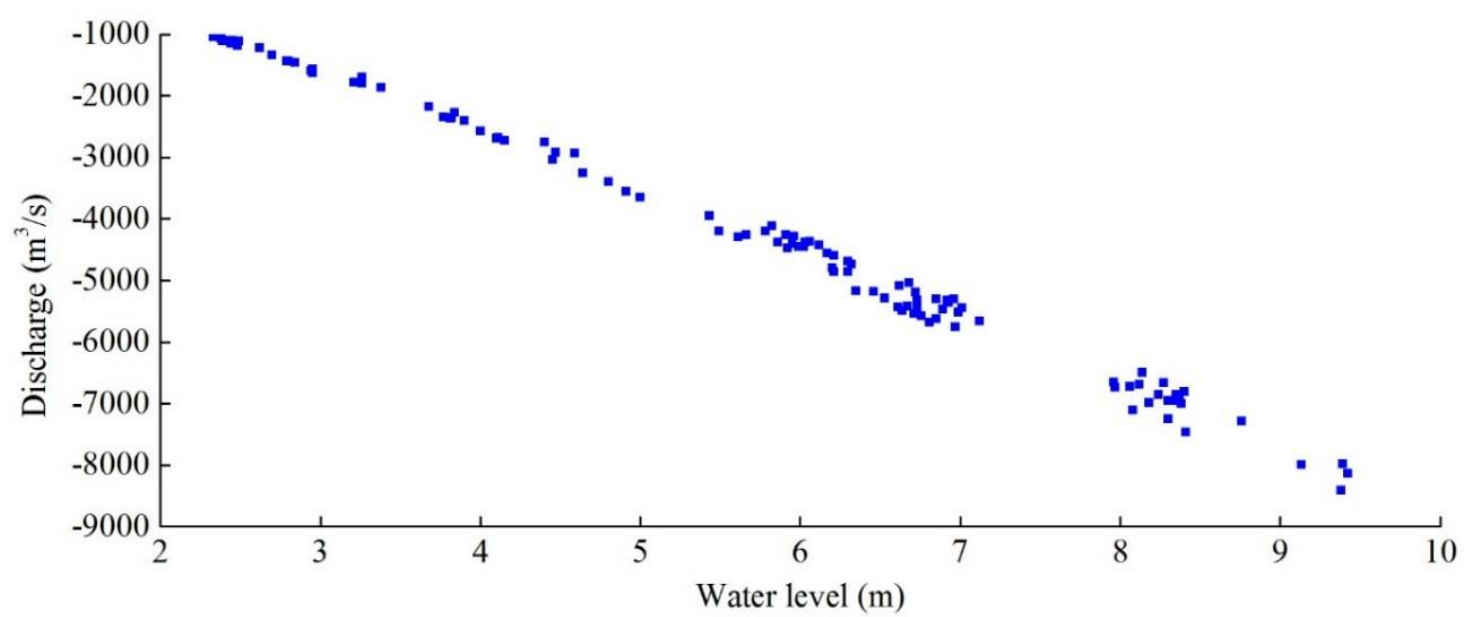

Figure 17. Correlation between water level and discharge of Prek Kdam station when the water level difference between Mekong River and Tonle Sap Lake reaches $0.8 \sim 1.0 \mathrm{~m}$

\section{Hydrological conditions of the reversal flow}

The time, duration and volume of reversal flow are closely linked to the hydrological conditions of Mekong River and Tonle Sap Lake. In light of the geomorphic and hydrological features of Cambodia Mekong Delta and Tonle Sap Lake area, this study selects the water level difference between Mekong River and Tonle Sap Lake (representing the flow resistance) and the water level at the Prek Kdam Station (representing the wetted cross-section area of Tonle Sap River) as the control indices to 
study the hydrological conditions of reversal flow. The water level difference between the Kompong Luong Station and Phnom Penh Station is the precondition for the reverse flow as it leads to a difference in the potential energy between the Mekong River and the Tonle Sap Lake. The water level at the Prek Kdam Station is the driving condition of the reversal. When the flow rate remains constant, the higher the water level is, the larger the wetted cross-section area of Tonle Sap River and the larger the discharge will be.

According to statistics from 1999 to 2011, the correlation between the reverse flow and the river-lake water level difference under different water levels at the Prek Kdam station is shown in Figure 18 and Table 1. It can be found that when the water level at the Prek Kdam station remains the same, the reverse flow increases with the increase of the water-level difference between Mekong River and Tonle Sap Lake; when the reverse flow remains the same, the river-lake water level difference declines with the increase of the water level at the Prek Kdam station; when the river-lake water-level difference remains the same, the reverse flow rises as the water level at the Prek Kdams station rises. The correlation coefficient between the reverse flow and the water-level difference between Mekong River and Tonle Sap Lake varies from 0.85 to 0.98 when the water level at the Prek Kdam station varies from 1.0 to $10.5 \mathrm{~m}$, and the correlation is stronger when the water level is higher.
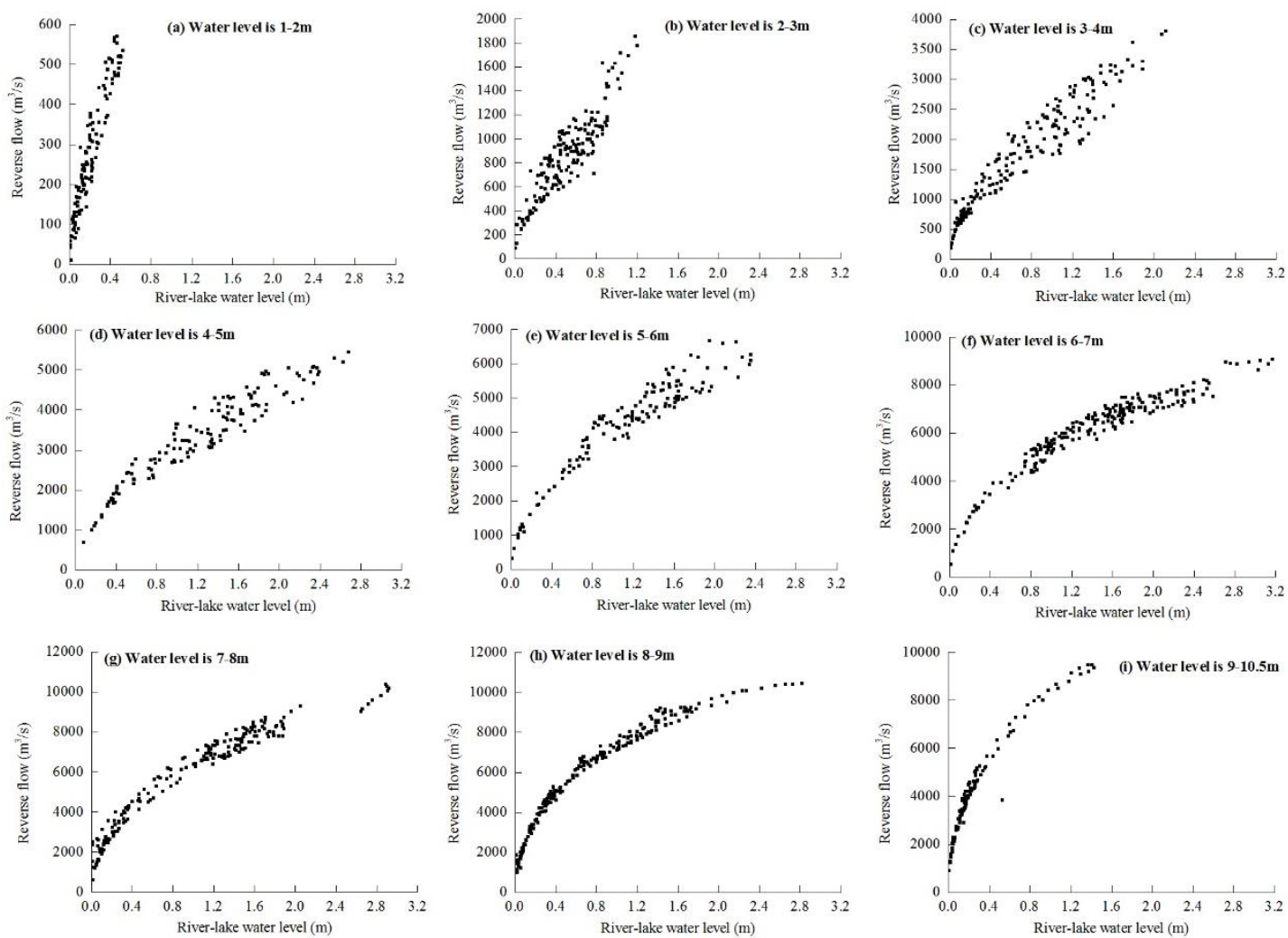

Figure 18. Correlation between reverse flow and river-lake water level difference

As the reverse flow and the water-level difference are positively correlated to the water level at the Prek Kdam station, the product of the water-level difference and the water level of the Prek Kdam station are set as the independent variable to identify its correlation to the reverse flow. On the basis of sufficient simulation and analyses, two 
respective power function coefficients are assigned to the water-level difference and the water level at the Prek Kdam station to reduce the error of simulation. On that basis, this study builds an optimization model for the correlation among the reverse flow, the water-level difference, and the water level at the Prek Kdam station, as shown in Equation 1 and Figure 19. It shows that the reverse flow is linearly correlated to the water-level difference and the water level at the Prek Kdam station, and the correlation coefficient reaches 0.9966 , which proves the rationality of the model.

$$
Q_{P K}=-413.73 H+80.54=-413.73 h_{P K}^{1.36}\left|h_{K L}-h_{J B G}\right|^{0.46}+80.54
$$

where $Q_{\mathrm{PK}}$ refers to the discharge $\left(\mathrm{m}^{3} / \mathrm{s}\right)$ at the Prek Kdam station; $h_{\mathrm{JBG}}, h_{\mathrm{PK}}$ and $h_{\mathrm{KL}}$ are the respective water level $(\mathrm{m})$ at the Phnom Penh station, the Prek Kdam station and the Kompong Luong station.

Table 1. Correlation coefficient between reverse flow and river-lake water level difference

\begin{tabular}{c|c|c|c}
\hline Water level of Prek Kdam station $(\mathbf{m})$ & $\mathbf{a}$ & $\mathbf{b}$ & ${\text { Correlation coefficient } \mathbf{R}^{\mathbf{2}}}$ \\
\hline $1.0 \sim 2.0$ & 852.49 & 0.7029 & 0.8751 \\
$2.0 \sim 3.0$ & 1264.3 & 0.5542 & 0.8489 \\
$3.0 \sim 4.0$ & 2203 & 0.5306 & 0.9554 \\
$4.0 \sim 5.0$ & 3059.3 & 0.5599 & 0.9472 \\
$5.0 \sim 6.0$ & 4072.1 & 0.5419 & 0.9753 \\
$6.0 \sim 7.0$ & 5318.6 & 0.4838 & 0.9757 \\
$7.0 \sim 8.0$ & 6321.5 & 0.4258 & 0.9247 \\
$8.0 \sim 9.0$ & 7304.9 & 0.4526 & 0.9690 \\
$9.0 \sim 10.5$ & 8549.5 & 0.4741 & 0.9779 \\
\hline
\end{tabular}

The correlation between the reverse flow and the water-level difference is presented as $Q_{\mathrm{PK}}=\mathrm{a} \cdot\left(h_{\mathrm{JBG}}-\right.$ $\left.h_{\mathrm{KL}}\right)^{\mathrm{b}}$, where $Q_{\mathrm{PK}}$ denotes the reverse flow at the Prek Kdam station $\left(\mathrm{m}^{3} / \mathrm{s}\right), h_{\mathrm{KL}}$ and $h_{\mathrm{JBG}}$ denote the respective level of water (m) at the Kompong Luong station and the Phnom Penh station; $\mathrm{a}$ and $\mathrm{b}$ are the fitting parameters

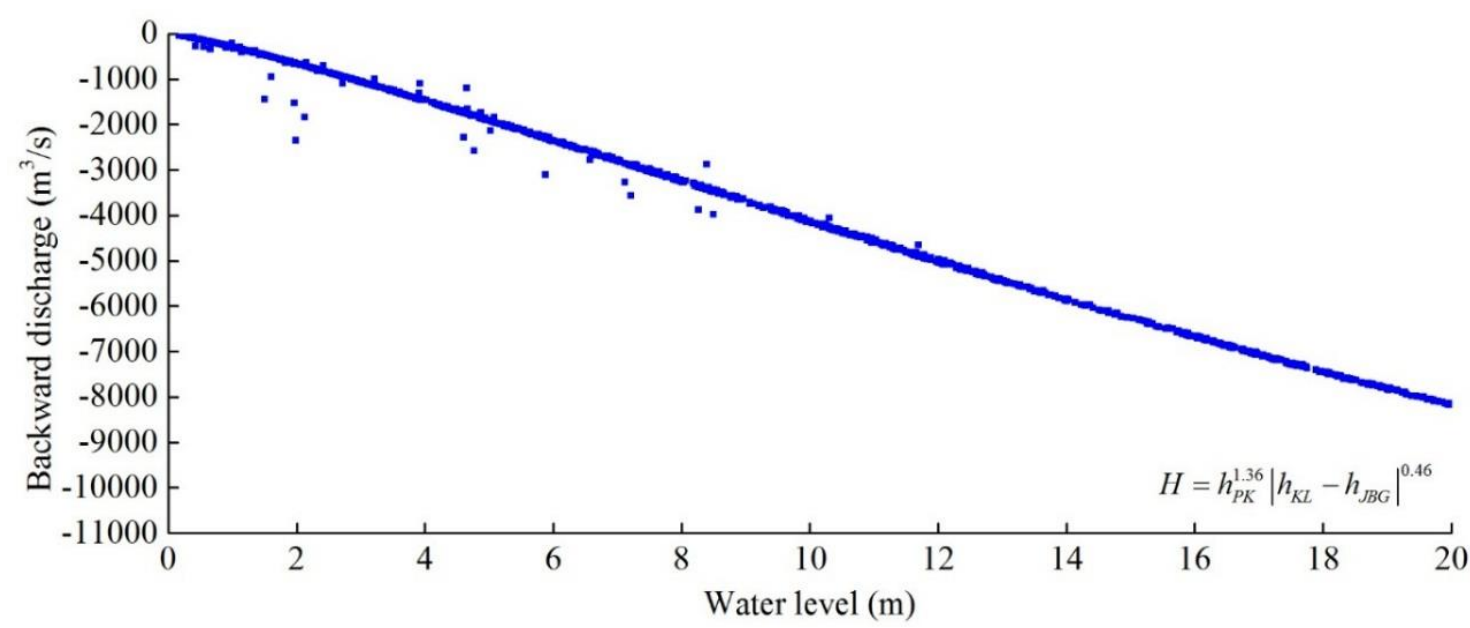

Figure 19. Correlation among reverse flow, water level difference and water level of Prek

\section{Kdam station}


According to quantitative analysis by Equation 1, the relationship among the reverse flow from Mekong River to Tonle Sap Lake, the water level at the Prek Kdam station and the difference in the water level between Mekong River and Tonle Sap Lake are achieved, as shown in Table 2. It shows that the reverse flow is small when the water level of Tonle Sap Lake is low or when the water level difference is small, and the reverse flow rises when the water level of Tonle Sap Lake or the hydraulic head difference increases. That is to say, the volume of reverse flow is positively correlated to the water level difference between Mekong River and Tonle Sap Lake. When the reverse flow reaches $3000 \mathrm{~m}^{3} / \mathrm{s}$, the required hydraulic head difference between Mekong River and Tonle Sap Lake declines from $1.31 \mathrm{~m}, 0.68 \mathrm{~m}, 0.40 \mathrm{~m}, 0.26 \mathrm{~m}$, $0.17 \mathrm{~m}$ to $0.12 \mathrm{~m}$ as the water level at the Prek Kdam station rises from $4 \mathrm{~m}, 5 \mathrm{~m}, 6 \mathrm{~m}$, $7 \mathrm{~m}, 8 \mathrm{~m}$ and $9 \mathrm{~m}$. When the water level at the Prek Kdam station remains at $8 \mathrm{~m}$, the respective reverse flow from Mekong River to Tonle Sap Lake are $3000 \mathrm{~m}^{3} / \mathrm{s}$, $4000 \mathrm{~m}^{3} / \mathrm{s}, 5000 \mathrm{~m}^{3} / \mathrm{s}, 6000 \mathrm{~m}^{3} / \mathrm{s}, 7000 \mathrm{~m}^{3} / \mathrm{s}, 8000 \mathrm{~m}^{3} / \mathrm{s}$ and $9000 \mathrm{~m}^{3} / \mathrm{s}$ when the hydraulic head difference between Mekong River and Tonle Sap Lake reaches $0.17 \mathrm{~m}$, $0.30 \mathrm{~m}, 0.48 \mathrm{~m}, 0.71 \mathrm{~m}, 0.99 \mathrm{~m}, 1.36 \mathrm{~m}$ and $1.84 \mathrm{~m}$. When the difference in the water level between Mekong River and Tonle Sap Lake is $1 \mathrm{~m}$, the respective water level of the Prek Kdam station needs to reach $2.11 \mathrm{~m}, 3.33 \mathrm{~m}, 4.38 \mathrm{~m}, 5.33 \mathrm{~m}, 6.23 \mathrm{~m}, 7.11 \mathrm{~m}$, $7.98 \mathrm{~m}, 8.88 \mathrm{~m}$ and $9.86 \mathrm{~m}$ so that the reverse flow can reach $1000 \mathrm{~m}^{3} / \mathrm{s}, 2000 \mathrm{~m}^{3} / \mathrm{s}$, $3000 \mathrm{~m}^{3} / \mathrm{s}, 4000 \mathrm{~m}^{3} / \mathrm{s}, 5000 \mathrm{~m}^{3} / \mathrm{s}, 6000 \mathrm{~m}^{3} / \mathrm{s}, 7000 \mathrm{~m}^{3} / \mathrm{s}, 8000 \mathrm{~m}^{3} / \mathrm{s}$ and $9000 \mathrm{~m}^{3} / \mathrm{s}$.

Table 2. Correlation among reverse flow from Mekong River to Tonle Sap Lake, river-lake water level difference and water level of Prek Kdam station

\begin{tabular}{|c|c|c|c|c|c|}
\hline \multirow{2}{*}{$\begin{array}{l}\text { Water level of } \\
\text { Prek Kdam } \\
\text { station }(\mathbf{m})\end{array}$} & \multicolumn{5}{|c|}{$\begin{array}{c}\text { Water level difference between Mekong River and Tonle Sap Lake }(\mathrm{m}) \text {, reverse } \\
\text { flow }\left(\mathrm{m}^{3} / \mathrm{s}\right)\end{array}$} \\
\hline & 0.1 & $\begin{array}{l}0.5 \\
\end{array}$ & 1 & 1.5 & 2 \\
\hline 2 & 245 & 634 & 920 & 1138 & 1322 \\
\hline 3 & 502 & 1194 & 1707 & 2099 & 2429 \\
\hline 4 & 798 & 1844 & 2622 & 3215 & 3711 \\
\hline 5 & 1127 & 2572 & 3642 & 4448 & 5113 \\
\hline 6 & 1487 & 3366 & 4737 & 5749 & 6564 \\
\hline 7 & 1875 & 4212 & 5877 & 7064 & 7981 \\
\hline 8 & 2289 & 5096 & 7022 & 8322 & 9259 \\
\hline 9 & 2727 & 6000 & 8126 & 9442 & 10275 \\
\hline 10 & 3185 & 6905 & 9137 & 10329 & 10885 \\
\hline
\end{tabular}

\section{Conclusion}

According to the statistical analysis, some conclusions are included as follows:

(1) The flood reversal flow from Mekong River lasts long and is large in volume during the flood season. For long series of years on average, the reversal lasts 122 days and the volume of reverse flow is 37.7 billion $\mathrm{m}^{3}$, with the flood peak remaining at $8402 \mathrm{~m}^{3} / \mathrm{s}$. The reversal volume accounts for $14 \%$ of the volume of Mekong River in the same time period and cuts $20 \%$ of the flood peak on average for years. The reversal occurs mainly from July to September and the maximum volume of reverse flow occurs in August, accounting for $43 \%$ of the volume in a whole year and $17.7 \%$ of the total volume from Mekong River in the same time period. The volume of reverse flow shows 
little change over the years and the extreme ratio of the volume and flood peak of reverse flow remain at 2.33 .

(2) The reverse flow is mainly subject to factors including the difference in runoff between Mekong River and Tonle Sap Lake, the difference in the water level between Mekong River and Tonle Sap Lake, and the water level of Tonle Sap River. Among these factors, the difference in runoff determines the difference in the water level. When the water level at Tonle Sap River remains constant, the volume of reverse flow increases as the difference in the water level between the river and the lake (flow resistance) increases. When the difference in the water level remains constant, the volume of reverse flow increases as the water level (the wetted cross-section area) of Tonle Sap River increases.

(3) The hydrological conditions of the reverse flow include the difference in the water level between the river and the lake and the water level at Tonle Sap River. When the water level of Mekong River exceeds that of Tonle Sap Lake, the reverse flow is linearly correlated to the product of the water level of Tonle Sap River to the power of 1.36 multiplied by that water-level difference between Mekong and Tonle Sap Lake to the power of 0.46. When the level of water at the Prek Kdam station on Tonle Sap Lake is $8 \mathrm{~m}$, the hydraulic head difference between the river and the lake needs to reach $0.17 \mathrm{~m}$, $0.30 \mathrm{~m}, 0.48 \mathrm{~m}, 0.71 \mathrm{~m}, 0.99 \mathrm{~m}, 1.36 \mathrm{~m}$ and $1.84 \mathrm{~m}$ so that the reverse flow can reach $3000 \mathrm{~m}^{3} / \mathrm{s}, 4000 \mathrm{~m}^{3} / \mathrm{s}, 5000 \mathrm{~m}^{3} / \mathrm{s}, 6000 \mathrm{~m}^{3} / \mathrm{s}, 7000 \mathrm{~m}^{3} / \mathrm{s}, 8000 \mathrm{~m}^{3} / \mathrm{s}, 9000 \mathrm{~m}^{3} / \mathrm{s}$ respectively. When the difference in the water level between the river and the lake is $1 \mathrm{~m}$, the water level at the Prek Kdam station has to reach $2.11 \mathrm{~m}, 3.33 \mathrm{~m}, 4.38 \mathrm{~m}, 5.33 \mathrm{~m}$, $6.23 \mathrm{~m}, 7.11 \mathrm{~m}, 7.98 \mathrm{~m}, 8.88 \mathrm{~m}$ and $9.86 \mathrm{~m}$, hence the reverse flow can reach $1000 \mathrm{~m}^{3} / \mathrm{s}$, $2000 \mathrm{~m}^{3} / \mathrm{s}, 3000 \mathrm{~m}^{3} / \mathrm{s}, 4000 \mathrm{~m}^{3} / \mathrm{s}, 5000 \mathrm{~m}^{3} / \mathrm{s}, 6000 \mathrm{~m}^{3} / \mathrm{s}, 7000 \mathrm{~m}^{3} / \mathrm{s}, 8000 \mathrm{~m}^{3} / \mathrm{s}, 9000 \mathrm{~m}^{3} / \mathrm{s}$, respectively.

Objective understanding the variation characteristics, influencing factors and hydrological conditions of the reverse flow from Mekong River to Tonle Sap Lake is conducive to the comprehensive management of Cambodia Mekong Delta and Tonle Sap Lake area. Limited to data conditions, this study is mainly based on the flow records from 1995 to 2011 and the water level records from 1999 to 2011, so further collection and analysis based longer series of hydrological data are needed in the future. The regulation and storage effect of Tonle Sap Lake on the flood of Mekong River, and the positioning of Tonle Sap Lake from the perspective of overall flood control of Mekong River should be further studied. In addition, in order to further study the internal mechanisms of the relationship between Mekong River and Tonle Sap Lake, the discharge capacity of Mekong River, the diversion flow and discharge sediments capacity of Tonle Sap River, the flood control capacity of Tonle Sap Lake should be considered, so it is recommended to strengthen the prototype observation of the river topography.

Acknowledgments. This research was financially supported by the National Key Research and Development Program of China (2017YFC0405301) and China-Asean Maritime Cooperation Fund "Langcang-Mekong Water Resources Cooperation Project".

\section{REFERENCES}

[1] Changiiang Institute of Survey, Planning, Design and Research (2015): Study on Variation and Influence of Relationship between Yangtze River and Poyang Lake. Changjiang Institute of Survey, Planning, Design and Research, Wuhan. 
[2] Changjiang Water Resources Commission of the Ministry of Water Resources (2013): Study on the Changes of Hydrological Regime in Poyang Lake and Related Influence on Water Control Project. - Changjiang Water Resources Commission of the Ministry of Water Resources, Wuhan.

[3] Changjiang Water Resources Commission of the Ministry of Water Resources (2019): Outline of Master Plan on Water Resources of Cambodian. - Changjiang Water Resources Commission of the Ministry of Water Resources, Wuhan.

[4] Cochrane, T. A., Arias, M. E., Piman, T. (2014): Historical impact of water infrastructure on water levels of the Mekong River and the Tonle Sap system. - Hydrology and Earth System Sciences 18(11): 4529-4541.

[5] Dai, X., Wan, R. R., Yang, G. S. (2015): Non-stationary water level fluctuation in China's Poyang Lake and its interactions with Yangtze River. - Journal of Geographical Sciences 25(3): 274-288.

[6] Fang, C. M., Cao, W. H., Mao, J. X., et al. (2012): Relationship between Poyang Lake and Yangtze River and influence of Three Georges Reservoir. - Journal of Hydraulic Engineering 43(2): 175-181.

[7] Guo, H., Hu, Q., Zhang, Q., et al. (2012): Effects of the Three Gorges Dam on Yangtze River flow and river interaction with Poyang Lake, China: 2003-2008. - Journal of Hydrology 416/417: 19-27.

[8] Hu, C. H., Ruan, B. Q. (2011): Study on key technologies of Poyang Lake water control project. - Journal of China Institute of Water Resources and Hydropower Research 9(4): 243-248.

[9] Hu, Q., Song, F., Guo, H., et al. (2007): Interactions of the Yangtze river flow and hydrologic processes of the Poyang Lake, China. - Journal of Hydrology 347(1/2): 90100.

[10] Huo, Y. (2011): Poyang Lake Morphological Characteristics and Its Response to Runoff and Sediment of Poyang Lake Basin. - Nanjing University, Nanjing.

[11] Li, C. W., You, Z. Q., Yao, W. (2018a): Study on the Flood Storage Function of Tonle Sap Lake. - Proceedings of 2018 Annual Conference of Chinese Hydraulic Engineering Society. Third Volume. China Water Power Press, Beijing.

[12] Li, C. W., Huang, L. Y., Wang, C. P., et al. (2018b): Study on Flood Control Planning of Mekong Delta in Cambodia. - Proceedings of 2018 Annual Conference of Chinese Hydraulic Engineering Society. Fifth Volume. China Water Power Press, Beijing.

[13] Li, C. W., You, Z. Q., Yao, W., et al. (2018c): Study on Hydrologic Condition of Water Exchange between Mekong River and Tonle Sap Lake. - Proceedings of 2018 Annual Conference of Chinese Hydraulic Engineering Society One Belt One Road-Go Out. Changjiang Press, Wuhan.

[14] Luo, X. P., Zheng, L., Qi, S. H., et al. (2008): Analysis on flow and sediment transportation variation of the Poyang Lake into the Yangtze River. - Yangtze River 39(6): 12-14.

[15] Mak, S., Pheng, S., Khuon, K., et al. (2012): Profile of the Sub-Area Stung Treng (SA9C). - Cambodia National Mekong Committee, Phnom Penh.

[16] Mekong River Commission (2005): Overview of the Hydrology of the Mekong Basin. Mekong River Commission, Vientiane, Laos.

[17] Mekong River Commission (2011): Atlas Planning of the Lower Mekong River Basin. Mekong River Commission, Phnom Penh.

[18] Republic of Korea, Korea International Cooperation Agency, Korea Water Resources Corporation (2008): Master Plan of Water Resources Development in Cambodia. Ministry of Water Resources and Meteorology, the Kingdom of Cambodia, Phnom Penh.

[19] Royal Haskoning, Deltares, UNESCO-IHE (2010): Structural Measures and Flood Proofing in the Lower Mekong Basin. - Mekong River Commission, Vientiane.

[20] Yin, H. F., Liu, G. R., Pi, J. G., et al. (2007): On the river-lake relationship of the middle Yangtze reaches. - Geomorphology 85(3/4): 197-207. 
[21] You, Z. Q., Yu, Q. H., Xu, Z. M. (2013): Master Plan on Poyang Lake Area. Proceedings of 2013 Annual Conference of Chinese Hydraulic Engineering Society. Chinese Hydraulic Engineering Society, Guangzhou.

[22] Zhang, Q., Ye, X. C., Werner, A. D., et al. (2014): An investigation of enhanced recessions in Poyang Lake: comparison of Yangtze River and local catchment. - Journal of Hydrology 517: 425-434.

[23] Zhang, Z. X., Chen, X., Xu, C. Y., et al. (2015): Examining the influence of river-lake interaction on the drought and water resources in the Poyang Lake basin. - Journal of Hydrology 522: 510-521.

[24] Zhong, Z. Y., Hu, W. Z. (2008): On relation of river and lake. - Yangtze River 39(1): 2022. 